\title{
The overview of cancer patients attending in a specialized hospital: A cross sectional study
}

\author{
Paul TK ${ }^{1}$, Banu $\mathrm{PA}^{2}$, Alam MSS 2 , Sharif $\mathrm{R}^{2}$, Rukhsana $\mathrm{N}^{2}$, Monower MM ${ }^{3}$ \\ ${ }^{1}$ Surgery Unit, Delta Medical College \& Hospital, Dhaka, ${ }^{2}$ Department of Oncology, Delta Medical \\ College \& Hospital, Dhaka, Bangladesh, ${ }^{3}$ Department of Epidemiology, Bangladesh Institute of Health \\ Sciences, Dhaka, Bangladesh. \\ Email: tapeshpaul@yahoo.com
}

\begin{abstract}
According to National Institute of Cancer Research and Hospital most frequently observed cancers in Bangladeshi population are lungs, breast, cervix, lymph node, esophagus, larynx and stomach. The point of epidemiological background, the rate of incidence and mortality are likely unavailable due to lack of population based cancer registry system in Bangladesh. This cross-sectional study was conducted from 2003 to 2012 with an aim to describe trends and pattern of cancer cases attended a specialized hospital in Dhaka city. A total of 29,999 cancer cases was enrolled and among them the male and female ratio was 1.2:1. The study revealed that around half of the patients attended from Dhaka division, followed by Chittagong division (22.9\%) and Sylhet division (8.8\%). According to the organ involvement most frequently reported malignancies in males were lung cancer $(24.2 \%)$, followed by eight percent larynx cancer and six percent lymph node cancer, whereas in females were breast cancer (27.5\%), followed by cervix cancer (19.5\%) and five percent lung cancer. It has been found that the system involvement was observed of cancers among male's respiratory system $(33.5 \%)$ followed by the digestive organs $(20.0 \%)$ and oral cavity $(14.2 \%)$ whereas in females were reproductive organs (26.3\%), followed by fourteen percent digestive organs and eight percent oral cancer. The overall cancer trend showed a gradual rise of cancer cases in both sexes. The rate was higher in females rather than male. Without the availability of population based registries, incidence and mortality figures; studies like the present one may provide useful leads for health planning and future exploration.
\end{abstract}

Key words: Cancer trend, Cancer pattern, Institution based study, Bangladesh

\section{Introduction}

Cancer was considered a disease of the affluent and the West, however, recent research has revealed it as a global epidemic. According to estimates from the International Agency for Research on Cancer (IARC), globally there were 14.1 million new cancer cases, 8.2 million cancer deaths and 32.6 million people living with cancer (within five years of diagnosis) in 2012. ${ }^{1}$ By 2030, the global burden is expected to grow to 23.6 million new cancer cases and this represents an increase of 68\% compared with 2012 (66\% in low and medium Human Development Index countries and 56\% in high and very high Human Development Index countries. ${ }^{1}$ About $30 \%$ of cancer deaths are due to the five leading behavioral and dietary risks: high body mass index, low fruit and vegetable intake, lack of physical activity, tobacco use and alcohol use. ${ }^{2}$ Tobacco use is the most important risk factor for cancer causing over $20 \%$ of global cancer deaths and about $70 \%$ of global lung cancer deaths. Cancer causing viral infections such as hepatitis B virus (HBV)/ hepatitis $\mathrm{C}$ virus (HCV) and human papilloma virus (HPV) are responsible for up to $20 \%$ of cancer deaths in low-income countries like Bangladesh. $^{2}$

Bangladesh, a republic of South Asia, is bordered on the west, north, and east by India, on the southeast by Burma (Myanmar), and on the south by the Bay of Bengal. Total population is around 150 million and male-female ratio is $100: 100.3 .^{3}$ 
Like many other countries in the world cancer in Bangladesh is one of the major killer diseases. Lung, breast, cervix, lymph node, esophagus, larynx and stomach cancer are the most common cancers in this country as indicated by National Institute of Cancer Research and Hospital $(\mathrm{NICRH}){ }^{4}$

At present, Bangladesh is growing with a good progress rate and it is hoped that it will become a developed country within a few decades resulting into its participation in the world development. Therefore, it is important to study the status of cancers in Bangladesh so that advance measures may be taken to control this havoc in near future. In view of these facts, attempts have been made to study the status of cancers in Bangladesh including its causes, preventive measures, effect on Bangladesh economy and comparison with global scenario.

Its personal, social and economic bearing is huge. To control cancer, proper data on cancer epidemiology is essential. Necessary epidemiological information like incidence and mortality data are unavailable as Bangladesh has no established population based cancer registry system. To determine the priorities for cancer control in different population groups epidemiological information on the pattern of cancer occurrence and trends can play an important role. This paper was an attempt to describe cancer trends and pattern among registered patients in a specialized hospital of Dhaka city.

\section{Materials and Methods}

The present hospital-based retrospective crosssectional study was conducted from the beginning of January, 2003 to the end of December, 2012 in Delta Medical College and Hospital (DLMCH) in Dhaka city. Cancer cases diagnosed by different methods like cytological and histological confirmation or treated during study period and was identified from the inpatient registers maintained by the medical records from the department of DLMCH. The primary site and morphology data were coded using the International Classification of Diseases (tenth Edition, ICD-10, World Health Organization); five precancerous lesions, foreign nationalities were excluded from the study. Medical records of identifying cases were reviewed and information on the date of diagnosis, primary site, histological findings, method of diagnosis and demographic data were retrieved. Duplicate cases were eliminated by crosschecking name, address, age and sex and hospital registration number of each patient. Data were entered and analyzed by using SPSS 16.0 version.

\section{Result}

The reviewed of the 10 years' documents in this study period, 29,999 cancer patients were eligible and included as a study participant where males were 16,362 (54.5\%) and females were 13,637 (45.5\%) and their ratio was 1.2:1. In males, mean age was 59.8 years and $\mathrm{SD} \pm 16.1$ and half of the cases were between 51 and 70 years. Among the male respondent's maximum frequency $(27.1 \%)$ observed in 51 to 60 years' age group. In females, mean age was 49.3 years and $\mathrm{SD} \pm 14.2$ and more than half of the cases were between 41 and 60 years. The highest frequency $(29.1 \%)$ observed in 41 to 50 years in female age group. In the middle age categories between 20 years and 50 years, the proportion of female cases were more than males and reverse frequency observed in older age categories (Fig. 1). Around half of the patients were attended from Dhaka division followed by more than one fifth proportion $(22.9 \%)$ from Chittagong division and around nine percent from Sylhet division.

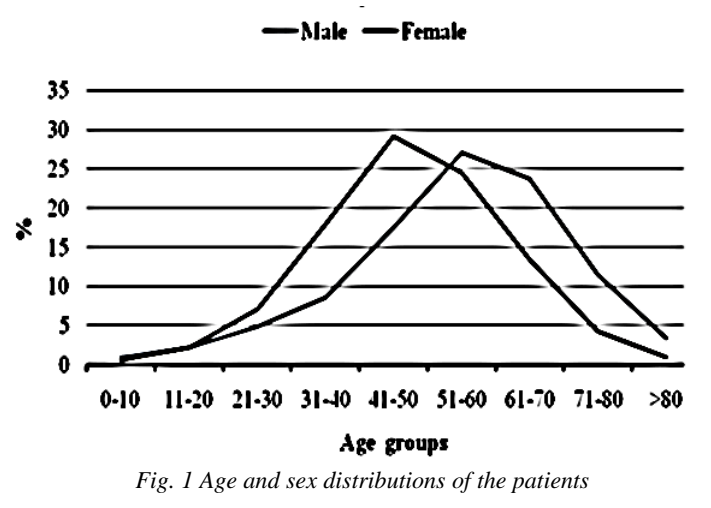

Among males, one third proportion of all cancer cases were confined to the respiratory system (C30-C34, C37-C38) followed by one fifth proportion digestive system (C15-C25) and fourteen percent oral cancer (C00-C14). In organ involvement around one fourth proportion (24.2\%) of all male cases were diagnosed as lung cancer (C33-C34) followed by eight percent 
larynx cancer (C32) and around six percent lymph node cancer (C81-C85). In females, more than one fourth proportion (27.5\%) of all cases was diagnosed as breast cancer (C50), another one fourth proportion $(26.3 \%)$ reproductive organs (C51-C58) followed by around fourteen percent digestive organs (C15-C25) and eight percent oral cancers (C00-C14). In the leading organ involvement after breast cancer, one fifth proportion $(19.5 \%)$ cases were cervix cancer (C53), followed by five percent lung cancer (C33C34). Highest number of cases reported as lung cancer in each year, which was higher (around 27\%) in 2005 and 2007 and then became steady from 2008 to 2012. Oral cancer was the second highest male cancer site which reported in similar pattern from 2003 to 2011 and lower frequency in 2012. Other cancer sites (larynx, lymphoma, esophagus, stomach) showed a steady manner in all ten years (Fig. 2).

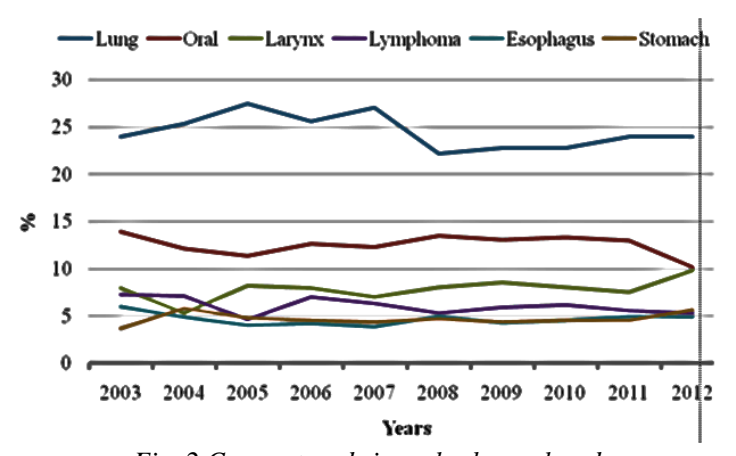

Fig. 2 Cancer trends in males by rank order

In female's breast cancer was the most frequent case in all 10 years and highest number (around $30 \%$ ) of cases reported in 2012. Cervix cancer was the second most frequent case which showed a zigzag manner in ten years. Highest number of cases reported (24.1\%) in 2006 then gradually fall to its lower limit (15.7\%) in 2009.

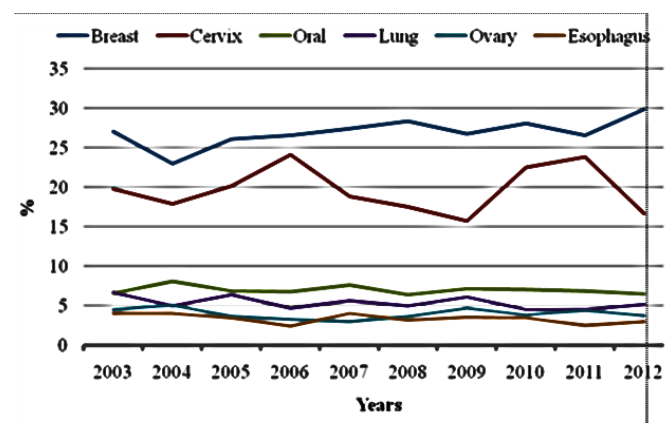

Fig. 3: Cancer trends in females by rank order
A sharp rise observed to its highest limit in 2010 and 2011 and again, it's gone downward in 2012. Other cancer sites (oral, lung, ovary and esophagus) were reported in similar patterns in all ten years (Fig. 3).

\section{Discussion}

In the present study, the proportion of male patients was more than females and the mean age of male patients were 10 years higher. The study revealed that maximum frequency observed in males $(27.1 \%)$ in 51 to 60 years' age group and in females $(29.1 \%)$ in 41 to 50 years' age group. It was observed that males developed tobacco related cancers and females developed breast and cervical cancer in higher proportion in those age groups.

In this study around one fourth proportion of all male cases were diagnosed as lung cancer (C33C34) and it was five percent in females. It ranked as a leading cancer site in males and third position in females. Worldwide, lung cancer also remained as the most frequent cancer site which comprises more than 1.8 million new cases and almost 1.6 million deaths, as estimated in $2012 .{ }^{6}$ In India, it accounts for $3.9 \%$ of global new cases and $4 \%$ of estimated global death. ${ }^{6}$ The observed variations in lung cancer rates and trends across countries or between males and females within each country largely reflect differences in the stage and degree of the tobacco epidemic. ${ }^{7,8}$ In a survey of tobacco use in Bangladesh, overall prevalence of smoking, chewing tobacco and gul (tobacco dust) usage were $20.5 \%, 20.6 \%$ and $1.8 \%$, respectively. Current smoking and gul usage were significantly higher in males $(42.2 \%$ and $2.2 \%$, respectively) than females $\left(2.3 \%\right.$ and $1.5 \%$, respectively). ${ }^{9}$ These factors might be responsible for higher proportion of lung cancer in males. The second most common organ cancer among males was larynx "C32" (eight percent of all male cases). Globally laryngeal cancer is the fourteenth most common cancer among men, but it is relatively rare in women. ${ }^{6}$

Highest number of cases reported (24.1\%) in 2006 then gradually fall to its lower limit $(15.7 \%)$ in 2009. This can be attributed to higher prevalence of smoking among males compared to females. ${ }^{9}$ Breast cancer (C50) is the most frequently diagnosed cancer and the leading cause of cancer death in females' worldwide, accounting for 1.7 
million new case and 0.5 million cancer deaths in $2012 .^{6}$

Table I: Cancer patient's distribution of both sexes; 20032012 summery

\begin{tabular}{|c|c|c|c|c|c|c|c|}
\hline \multirow{2}{*}{ Site/s } & \multirow{2}{*}{$\begin{array}{c}\text { ICD } \\
10 \\
\text { code/s }\end{array}$} & \multicolumn{2}{|c|}{$\begin{array}{c}\text { Male } \\
\mathrm{n}=16362\end{array}$} & \multicolumn{2}{|c|}{$\begin{array}{c}\text { Female } \\
\mathrm{n}=13637\end{array}$} & \multicolumn{2}{|c|}{$\begin{array}{c}\text { Total } \\
\mathrm{n}=29999\end{array}$} \\
\hline & & $\mathbf{n}$ & $\%$ & $\mathbf{n}$ & $\%$ & $\mathbf{n}$ & $\%$ \\
\hline $\begin{array}{l}\text { Lip, oral } \\
\text { cavity and } \\
\text { pharynx }\end{array}$ & $\begin{array}{l}\mathrm{C} 00- \\
\mathrm{C} 14\end{array}$ & 2326 & 14.2 & 1095 & 8.0 & 3421 & 11.4 \\
\hline $\begin{array}{c}\text { Digestive } \\
\text { organs }\end{array}$ & $\begin{array}{l}\text { C15- } \\
\text { C25 }\end{array}$ & 3272 & 20.0 & 1887 & 13.8 & 5159 & 17.2 \\
\hline Oesophagus & $\mathrm{C} 15$ & 763 & 4.7 & 440 & 3.2 & 1203 & 4.0 \\
\hline Stomach & $\mathrm{C} 16$ & 775 & 4.7 & 322 & 2.4 & 1097 & 3.7 \\
\hline $\begin{array}{c}\text { Small } \\
\text { intestine }\end{array}$ & $\mathrm{C} 17$ & 12 & 0.1 & 4 & 0.0 & 16 & 0.1 \\
\hline Colon & $\mathrm{C} 18$ & 451 & 2.8 & 306 & 2.2 & 757 & 2.5 \\
\hline Rectum & $\begin{array}{l}\text { C19- } \\
\text { C20 }\end{array}$ & 335 & 2.0 & 183 & 1.3 & 518 & 1.7 \\
\hline Anus & $\mathrm{C} 21$ & 52 & 0.3 & 36 & 0.3 & 88 & 0.3 \\
\hline Liver & $\mathrm{C} 22$ & 429 & 2.6 & 134 & 1.0 & 563 & 1.9 \\
\hline Gall bladder & $\begin{array}{l}\mathrm{C} 23- \\
\mathrm{C} 24\end{array}$ & 201 & 1.2 & 353 & 2.6 & 554 & 1.8 \\
\hline Pancreas & $\mathrm{C} 25$ & 254 & 1.6 & 109 & 0.8 & 363 & 1.2 \\
\hline $\begin{array}{c}\text { Respiratory } \\
\text { and } \\
\text { intrathoracic } \\
\text { organs }\end{array}$ & $\begin{array}{l}\text { C30- } \\
\text { C34, } \\
\text { C37- } \\
\text { C38 }\end{array}$ & 5478 & 33.5 & 959 & 7.0 & 6437 & 21.4 \\
\hline Larynx & C32 & 1311 & 8.0 & 141 & 1.0 & 1452 & 4.8 \\
\hline Lung & $\begin{array}{l}\text { C33- } \\
\text { C34 }\end{array}$ & 3960 & 24.2 & 712 & 5.2 & 4672 & 15.6 \\
\hline $\begin{array}{l}\text { Bone and } \\
\text { articular } \\
\text { cartilage }\end{array}$ & $\begin{array}{l}\mathrm{C} 40- \\
\mathrm{C} 41\end{array}$ & 166 & 1.0 & 105 & 0.8 & 271 & 0.9 \\
\hline Skin & $\begin{array}{l}\mathrm{C} 43- \\
\mathrm{C} 44\end{array}$ & 299 & 1.8 & 166 & 1.2 & 465 & 1.6 \\
\hline $\begin{array}{l}\text { Mesothelial } \\
\text { and soft } \\
\text { tissue }\end{array}$ & $\begin{array}{c}\text { C45 \& } \\
\text { C47- } \\
\text { C49 }\end{array}$ & 314 & 1.9 & 189 & 1.4 & 503 & 1.7 \\
\hline Breast & C50 & 46 & 0.3 & 3746 & 27.5 & 3792 & 12.6 \\
\hline $\begin{array}{c}\text { Female } \\
\text { genital } \\
\text { organs }\end{array}$ & $\begin{array}{l}\text { C51- } \\
\text { C58 }\end{array}$ & 0 & 0 & 3582 & 26.3 & 3582 & 11.9 \\
\hline Vulva & C51 & & & 39 & 0.3 & & \\
\hline Vagina & C52 & & & 76 & 0.6 & & \\
\hline Cervix & C53 & & & 2664 & 19.5 & & \\
\hline Uterus & $\begin{array}{l}\text { C54- } \\
\text { C55 }\end{array}$ & & & 216 & 1.6 & & \\
\hline Ovary & $\begin{array}{l}\text { C56- } \\
\text { C57 }\end{array}$ & & & 543 & 4.0 & & \\
\hline
\end{tabular}

In our study breast cancer also diagnosed as most common cancer among females and it was estimated more than one fourth proportion of all female cases. In 2012, 8.6\% of new global cases and $13.5 \%$ estimated death occurred in India. ${ }^{6}$ Recent reports of registries of that country has shown that breast cancer incidence has overtaken cervix cancer incidence. ${ }^{10}$

Table II: Cancer patient's distribution of both sexes; 2003-2012 summery (continue)

\begin{tabular}{|c|c|c|c|c|c|c|c|}
\hline \multirow[t]{2}{*}{ Site/s } & \multirow{2}{*}{$\begin{array}{c}\text { ICD 10 } \\
\text { code/s }\end{array}$} & \multicolumn{2}{|c|}{$\begin{array}{c}\text { Male } \\
\mathrm{n}=16362\end{array}$} & \multicolumn{2}{|c|}{$\begin{array}{c}\text { Female } \\
\mathbf{n}=\mathbf{1 3 6 3 7}\end{array}$} & \multicolumn{2}{|c|}{$\begin{array}{c}\text { Total } \\
\mathrm{n}=29999\end{array}$} \\
\hline & & $\mathbf{n}$ & $\%$ & $\mathbf{n}$ & $\%$ & $\mathrm{n}$ & $\%$ \\
\hline $\begin{array}{l}\text { Male } \\
\text { genital } \\
\text { organs }\end{array}$ & C60-C63 & 631 & 3.9 & 0 & $\mathbf{0}$ & 631 & 2.1 \\
\hline Penis & C60 & 28 & 0.2 & & & & \\
\hline Prostate & C61 & 435 & 2.7 & & & & \\
\hline Testis & C62 & 163 & 1.0 & & & & \\
\hline $\begin{array}{l}\text { Urinary } \\
\text { tract }\end{array}$ & C64-C68 & 629 & 3.8 & 207 & 1.5 & 836 & 2.8 \\
\hline Kidney & $\begin{array}{c}\text { C64-C66, } \\
\text { C68 }\end{array}$ & 263 & 1.6 & 122 & 0.9 & 385 & 1.3 \\
\hline Bladder & C67 & 366 & 2.2 & 85 & 0.6 & 451 & 1.5 \\
\hline $\begin{array}{c}\text { Eye, } \\
\text { brain and } \\
\text { other } \\
\text { parts of } \\
\text { central }\end{array}$ & C69-C72 & 563 & 3.4 & 283 & 2.1 & 846 & 2.8 \\
\hline Brain & C70-C72 & 527 & 3.2 & 256 & 1.9 & 783 & 2.6 \\
\hline $\begin{array}{l}\text { Thyroid } \\
\text { and other } \\
\text { endocrine } \\
\text { glands }\end{array}$ & C73-C75 & 139 & 0.8 & 239 & 1.8 & 378 & 1.3 \\
\hline Thyroid & C73 & 128 & 0.8 & 228 & 1.7 & 356 & 1.2 \\
\hline $\begin{array}{c}\text { Ill- } \\
\text { defined, } \\
\text { other } \\
\text { secondary } \\
\text { and } \\
\text { unspecifie }\end{array}$ & C76-C80 & 1236 & 7.6 & 669 & 4.9 & 1905 & 6.4 \\
\hline $\begin{array}{c}\text { Lympho } \\
\text { ma }\end{array}$ & C81-C85 & 965 & 5.9 & 362 & 2.6 & 1327 & 4.4 \\
\hline $\begin{array}{c}\text { Hematop } \\
\text { oietic and } \\
\text { related } \\
\text { tissue }\end{array}$ & $\begin{array}{c}\text { C88, } \\
\text { C90-C92, } \\
\text { C94 \& } \\
\text { C96 }\end{array}$ & 221 & 1.4 & 97 & 0.7 & 318 & 1.1 \\
\hline $\begin{array}{c}\text { Uncertain } \\
\text { behavior } \\
\text { of } \\
\text { endocrine } \\
\text { glands }\end{array}$ & D44 & 52 & 0.3 & 40 & 0.3 & 92 & 0.3 \\
\hline $\begin{array}{c}\text { Neuroendo } \\
\text { crine } \\
\text { tumors }\end{array}$ & C7A & 25 & 0.2 & 11 & 0.1 & 36 & 0.1 \\
\hline
\end{tabular}

Reproductive factors that increase risk include a long menstrual history, null parity, recent use of postmenopausal hormone therapy or oral contraceptives, and late age at first birth increases the risk of breast cancer.11 These factors might be responsible for high frequency of breast cancer in this country.

In this study, cervix cancer (C53) was the second leading cancer site among females. Cervical cancer is the fourth most common cancer (528,000 new cases) and the fourth most common cause of cancer death (266,000 deaths) in women worldwide, as estimated in 2012. Almost $70 \%$ of 
the global burden occur in areas with low or medium levels of human development, and more than one fifth of all new cases of cervical cancer are diagnosed in developing countries.6 Risk factors like early age at marriage, early age at first coitus, early age at first childbirth, sex with uncircumcised men, multiparity, low socioeconomic status and poor genital hygiene are responsible for high incidence of cervix cancer in underdeveloped regions. Besides these risk factors, it has now been established that infection with the oncogenic subtypes of human papilloma viruses (HPV) is the necessary cause for cervical cancer.12 This high burden of cervical cancer might be due to lack of screening that allows detection of precancerous and early stage cervical cancer.

According to system involvement digestive organs (C15-C25) were the second most common cancer area in males and third leading cancer in females. Oesophageal and stomach cancer simultaneously took the fourth leading position in males whereas fifth and seventh leading site in females respectively. Oesophageal cancer is the eighth most common and stomach cancer is the fifth most common cancer worldwide in 2012. Almost three quarters of the new cases occurred in Asia, and more than six percent occurred in India.6 Third most common cancer site in males was lymphoma "C81-C85" (six percent of all male cases). There were almost 566,000 new cases of lymphoma worldwide in 2012, and about 305,000 deaths. ${ }^{6}$ The exact causes for this increase are not entirely clear, but could be related to altered immune function associated with older age as well as HCV infection, which is preventable.

In relation to system involvement, oral cavity cancer (C00-C14) was the third most common cancer area in males ( $14.2 \%$ of all male cases) and fourth common cancer in females (8\% of all female cases). For cancers of the oral cavity and pharynx, an estimated 529,000 new cases occurred worldwide in 2012, with 292,000 deaths. ${ }^{6}$ The highest incidence rates are in Papua New Guinea, Bangladesh, Hungary, and Sri Lanka. Smokeless tobacco products and betel quid with or without tobacco are the major risk factors for oral cavity cancer in India, and other neighboring countries. ${ }^{13}$

In the cancer trend a gradual rise of cancer cases observed from 2003 to 2012 in both sexes. Similar trend found in another study from India in which data were compiled from 2004 to $2010 .{ }^{14}$ This gradual rise might be due to the high prevalence of tobacco use, the absence of early detection, screening and intervention to cancer control.

The findings of this study showed the 10-year cancer scenario of a specialized cancer hospital. These results cannot be extrapolated to the entire nation due to referral and other biases regarding hospital data. Hence population-based cancer registries should be established within the region to ensure proper documentation and research on malignant diseases.

In the absence of population based registries, and where the incidence and mortality figures are not available, studies like the present one may provide useful leads for health planning and future research.

\section{Acknowledgement:}

The authors gratefully acknowledge all the patients in the study, Chairman of the hospital, all doctors and record keeper of the instituted for their support and encouragements.

\section{References}

1. International Agency for Research on Cancer [Internet]. France: Estimated Cancer Incidence, Mortality and Prevalence Worldwide in 2012 [cited 2014 March 15]. Available from: http://globocan.iarc.fr/Default.aspx

2. World Health Organization (WHO) [Internet]. Cancer [cited 2014 March 20]. Available from: http://www.who.int/mediacentre/factsheets/fs297/en

3. Statistics and Informatics Division [Internet]. Bangladesh: Bureau of Statistics; 2013 [cited 2014 February 18]. Available from: http://www.bbs.gov.bd/home.aspx

4. National Institute of Cancer Research and Hospital [Internet]. Bangladesh: Cancer Registry Report: 2005-2007 [cited 2014 February 25]. Available from: http://nicrhbd.org/images/Publication_Cancer_Regis try_Report.pdf

5. World Health Organization [Internet]. International Statistical Classification of Diseases and Related Health Problems, 2011 [cited 2014 March 13]. Available

from:http://www.who.int/classifications/icd/ICD10 Volume2_en_2010.pdf

6. Stewart BW and Wild CP. World cancer report 2014 [Internet]. Lyon, France: International Agency for Research on Cancer, Geneva, Switzerland [cited 2014 February 8]. Available from WorldCat: http://www.worldcat.org/title/world-cancer-report2014/oclc/903962851 
7. Youlden DR, Cramb SM, Baade PD. The International Epidemiology of Lung Cancer: geographical distribution and secular trends. J Thorac Oncol. 2008;3: 819-31.

8. Bray FI, Weiderpass E. Lung cancer mortality trends in 36 European countries: secular trends and birth cohort patterns by sex and region 1970-2007. Int J Cancer. 2010; 126:1454-66.

9. Flora MS, Mascie-Taylor CGN, Rahman M. Gender and locality differences in tobacco prevalence among adult Bangladeshis. Tobacco Control. 2009; 18:44550 .

10. Indian Council of Medical Research. Population Based Cancer Registries under North Eastern Regional Cancer Registry First Report: 2003-2004. Bangalore: Ministry of Health; 2006.
11. Hulka BS, Moorman PG. Breast cancer: hormones and other risk factors. Maturitas. 2001;38: 103-13.

12. Hakama M, Miller AB, Day NE. Screening for cancer of the uterine cervix. 1st ed. IARC Sci Pub: Oxford University Press; 1987.

13. Jayalekshmi PA, Gangadharan P, Akiba S, Nair RR, Tsuji M, Rajan B. Tobacco chewing and female oral cavity cancer risk in Karunagappally cohort, India. $\mathrm{Br}$ J Cancer. 2009;100: 848-52.

14. Imran A, Waseem A, Wani, Saleem K. Cancer Scenario in India with Future Perspectives. Cancer Therapy. 2011; 8: 56-70. 